症例

\title{
肝外発育型肝細胞癌摘除後多数の肝内, 腹腔内転移を
}

\section{認めながら 4 年間生存し得た症例}

\begin{tabular}{|c|c|c|c|c|c|c|c|c|c|c|}
\hline \multirow[b]{2}{*}{ 小 } & \multicolumn{5}{|c|}{ 群馬大学第 1 外科 } & \multicolumn{3}{|c|}{ （長町幸雄教授） } & \multirow[b]{2}{*}{ 雅 } & \\
\hline & 暮 & 公 & 䓔 & 石 & 崎 政 & 利 & 根 & 本 & & 明 \\
\hline 中 & 屋 & 光 & 雄 & 安 & 藤 & 哲 & 栗 & 原 & & 15 \\
\hline & & & & & 会前橋 & 育院 & & & & \\
\hline & & & & & 本 & 潔 & & & & \\
\hline
\end{tabular}

58葴，女性. $15 \mathrm{~kg}$ の体重減少と腹部腫癐を主訴とした肝外発育型肝細胞癌症例を释験 したが腫瘤は右肝動脈前下区域枝に栄養され懸垂状に骨盤まで達していた。右肝動脈を 結禁切断後, 被膜に沿って剝離するように腫晹を摘出したが組織学的には索状型, 充実 型，偽腺管型，硬化型等多彩な組織像を示した。㭪後15カ月，腹壁と肝内に転移巣を認 め腹壁の転移巣を摘除した。㭪後20カ月目には腹腔内への転移も認められ，術後 30 カ 後には空腸間膜の転移巣が摘除された。この間, 2 回の MMC20mg の肝動注と他の抗癌 剂の投与が行われたが術後48カ月目に転移巣增大と腸通過障害による全身哀弱により死 亡した．本例は肝外発育型の内の肝外突出型肝緗胞癌の範疇に入り本邦報告62例中では 4 年生存したすのはなく生存期間に於いてもまれな症例と考え若干の文献的考察を加光 て報告した。

柬引用語：肝細胞癌，肝外発育型，肝外突出型

はじめに

肝外発育型肝細胞癌は比較的をれな疾患で遠近》に よればこれまで本邦では62例が報告されているに過ぎ ず，また，比較的進展した状態で発見される場合が多 く3 年以上生存したものは 2 例に過ぎない。肝右葉前 下区域からの肝外発育型肝細胞癌摘除後，肝内と腹腔 内並びに腹壁筋風内に多数の転移巣を有しながら 4 年 間生存し得た症例を経耠したので報告する。

\section{症例}

患者：58歳女性

主訴：腹部畽瘤, 体重減少, 味覚变化,

家族歴：特記すべきことなし

既往歴：50歳より白内障, 高血压症

㖓好：欲酒歴，喫煙歴共になし

現病歴：昭和58年 9 月頃より体重減少 (7kg) と味覚 の変化にきずき胃の X 線検査を受けたが異常を認め なかった。昭和59年 6 月20日体重减少 (更に8kg)が続 くため某医を受診し腹部腫瘤を指摘摘され 6 月 25 日済

1989年11月17日受付 1990 年 4 月17日採用
生会前橋病院に入院した。

第 1 回入院時所見：体重 $38 \mathrm{~kg}$ (昭和58年 9 月52kg). 黄疸，負血はなく食事摄取も良好で胸部には異常所見 を認めなかった，腹部は平坦で变色，静脈怒張を認め なかったが右上腹部に表面平滑，弾性硬，小児頭大の 可動性の腫瘤を触知した（図 1 ).

検查所見：RBC $423 \times 10^{4} / \mathrm{mm}^{3}, \mathrm{Hb} 12.3 \mathrm{~g} / \mathrm{dl}$ と費 血はなく，肝機能はGOT72IU，GPT79IU，LDH445 WU と軽度異常を認めたが TTT0.9U, ZTT3.4U, Total bilirubin $0.6 \mathrm{mg} / \mathrm{dl}, \mathrm{ICG}_{15} 2.1 \%$, アンモ $=775$ $\gamma / \mathrm{dl}$ と肝硬变の所見は認められなかった. ブドウ糖負 荷試験では境界型を示したが留機能には異常を認め ずまた，血清アミラーぜ值は266IU，尿アミラーぜ値 は2270IU とほぼ正常であった. HBS-Ag (一), AFP (一), CEA 2ng $/ \mathrm{ml}$ と畽場マーカーは共に陰性を示し た.

画像診断：超音波ならびにCT の所見では腫掦は実 質性で明瞙な被膜に包まれ被膜部分は造影剂で濃染 し，畽瘤実質部分む造影剤により，やや高濃度に造影 されている．また，畽瘤中央腹側には高輝度の石灰化 


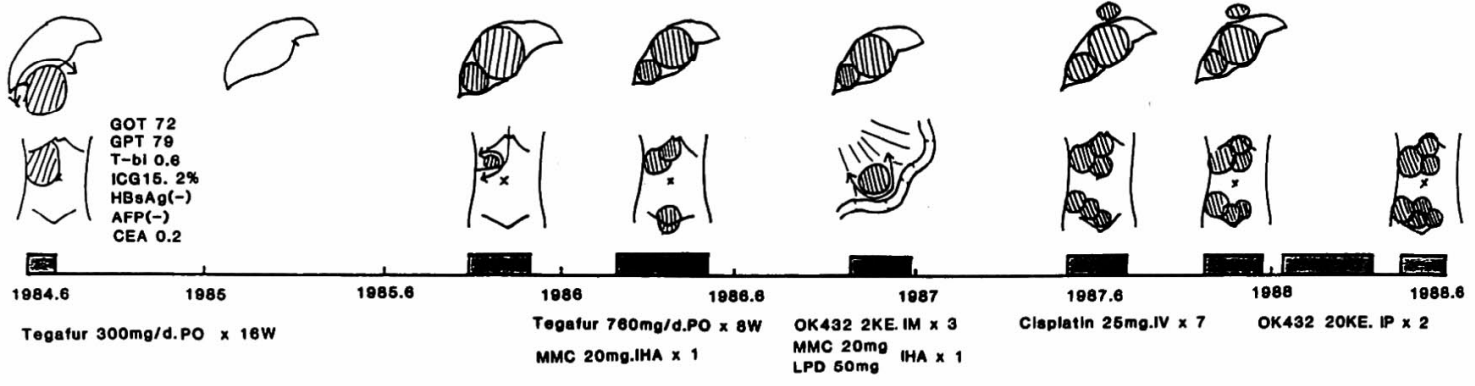

图 1 症例の臨床経過 : $\mathrm{PO}=$ =経口摂取. $\mathrm{IHA}=$ 肝動脈注. $\mathrm{IV}=$ 静脈注. $\mathrm{IP}=$ 腹腔内注.

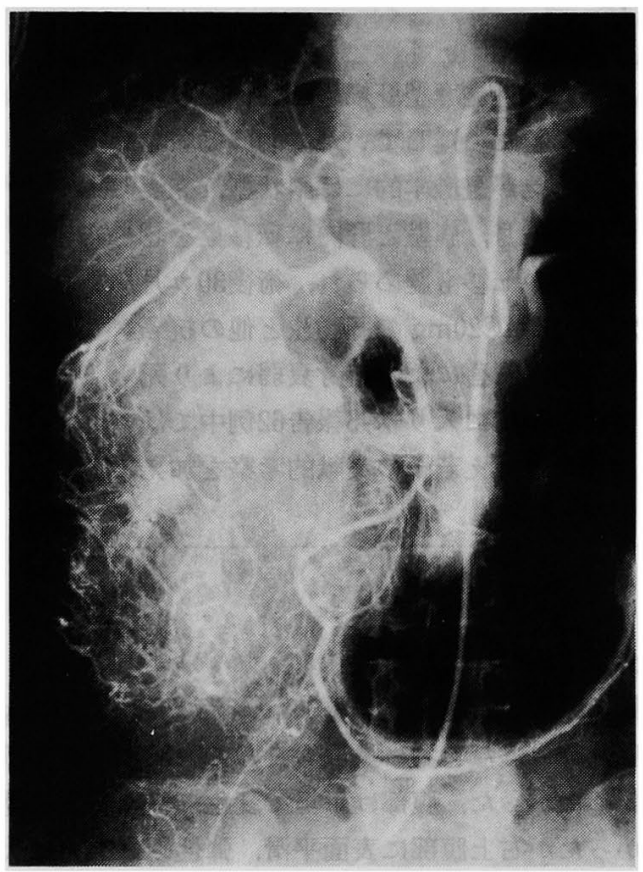

図2 入院時血管造影像：右前下区域枝が拡張し懸垂 状に骨盤に達する腫痬には著しい血管増生が認めら れる.

像を認めるが周囲臓器への侵潤は認めない. 血管造影 所見では右肝動脈の前下区域枝が拡張し栄養動脈と なっている，血管増生が著明で一部に造影剂の貯留を 認め, 肝とは明らかに境界され懸垂状に骨盤まで下垂 しているが他葴器からの栄養血管の新生を認めない (図 2 ).

手術所見：逆 L 型切開で開腹すると腫瘍は厚い被 膜に覆われ胆壕床の右側の肝右葉前下区域の一部から 肝外性に発育し骨盤上部に達していた。肝への付着部 近傍中央部が浅く陥凹し硬い骨質の部分を認め被膜内 には多数の拍動性に怒張した血管が認められたが他臓

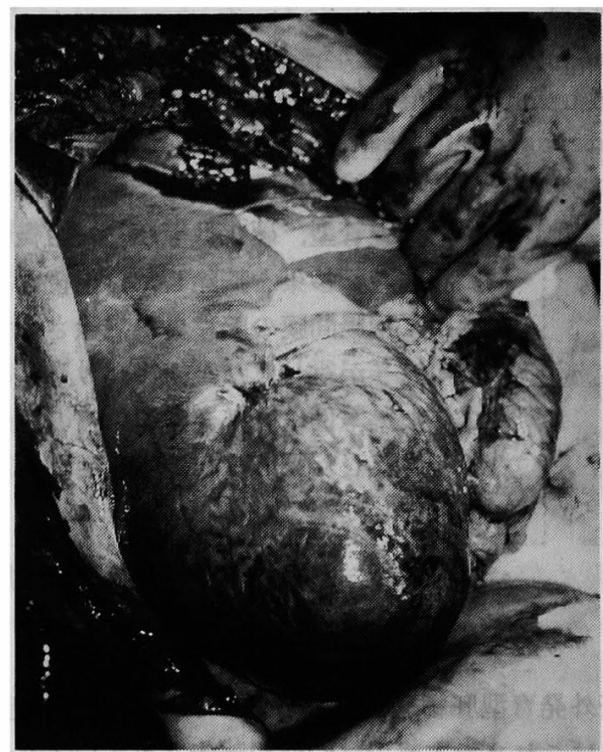

図 3 術中写真：重瘍はラグビーボール状で被膜に覆 われ多数の拍動した血管が透見される.肝との境界 近く石灰化部位が認められる.

器への侵潤は認められなかった。肝は肉眼的にほぼ正 常で肝硬変, 肝内転移巣は認めなかった。右肝動脈を 結禁切断後, 正常肝と腫瘍との境界を腫瘍に入る栄養 血管を結禁切断しつつ剝離するようにこれを摘除し た。腫場の大きさは $11 \times 8 \times 13 \mathrm{~cm}$. 重量 $600 \mathrm{~g}$ であった (図 3 ).

組織学的所見：腫瘍は一部の硬い石灰化部分を除い てすべて充実性で組織学的には EdII-IIIで索状型 (A), 充実型 (B), 為腺管型 (C), 硬化型 (D) と多 彩な組織像を示した。 また，著しく血管に富む部分(B) 々血管成分の少ない部分に分かれていた，石灰化部分 は結合織に包まれていたが骨細胞は認めなかった（図 4 ). 

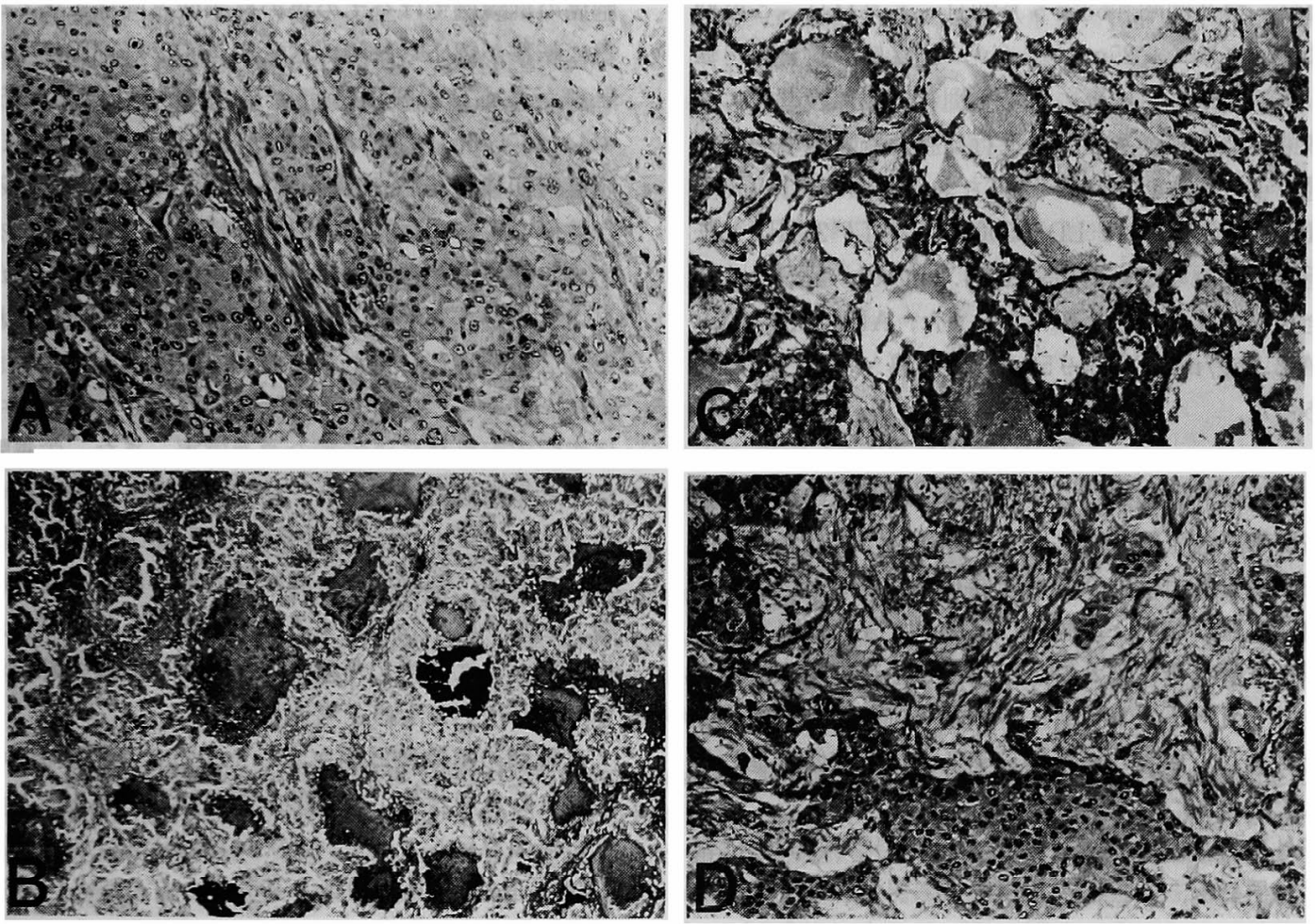

図4 組織学的所見：多彩な組織像が認められた。 A : 索状型, $\mathrm{HE} \times 80 . \mathrm{B}$ : 充実型, $\mathrm{HE} \times 30$ ，血液を含む多数の血管が認められる，C：偽腺管型， $\mathrm{HE} \times 80 . \mathrm{D}$ ：硬化 型 $\times 80$

第 2 回入院：術後経過良好で昭和 59 年 7 月 28 日に退 院したが昭和60年 9 月 5 日 CT 上で創部腹壁筋層に小 手㚐大の腫瘤と訮内に 3 個の転移巣が認められたため 再入院し昭和 60 年 9 月 11 日腹壁層の腫瘤を摘出した. 組織学的には原発巣と類似の所見を示した。肝内転移 に対しては Tegaful $300 \mathrm{mg} \times 16 \mathrm{~W}$ を経口投与し, 全身 状態が改善したため昭和60年10月22日退院した。

第 3 回入院：昭和 60 年 2 月 19 日 5 月 12 日全身衰弱 と新たに腫瘤が下腹部に触知されたため入院したが Tegaful $750 \mathrm{mg} \times 8 \mathrm{w}$ と MMC20mg 肝動注並びに保 存的治療により全身状態の改善を見たため退院した。

第 4 回入院：昭和61年11月 5 日 12月27日再び全身 衰弱で入院. CT では肝内転移巣の増大, 腹腔内にも新 たに別の転移巣が認められたため肝動脈結禁の目的で 開腹したが増大した腫瘍により肝門部への到達が困難 であったためこれを断念した。その際，腸間膜に多数 の小指頭大から母指頭の孤立性の転移巣を認めたが, 特に, 空腸中央部の腸間膜付着部に手拳大の転移巣を 認めこれが腸管を圧排し将来，腸の通過障害を起こす
恐れがあったためこれを摘除した．組織学的には原発 巣と類似の所見を示した。 OK432.2KE×3（im）. MMC20mg, LPD50mgの肝動注を行った。

第 5 回昭和 62 年 5 月 25 日 7 月 22 日, 第 6 回昭和 62 年10月19日～12月 27 日，第 7 回昭和 63 年 1 月 18 日 4

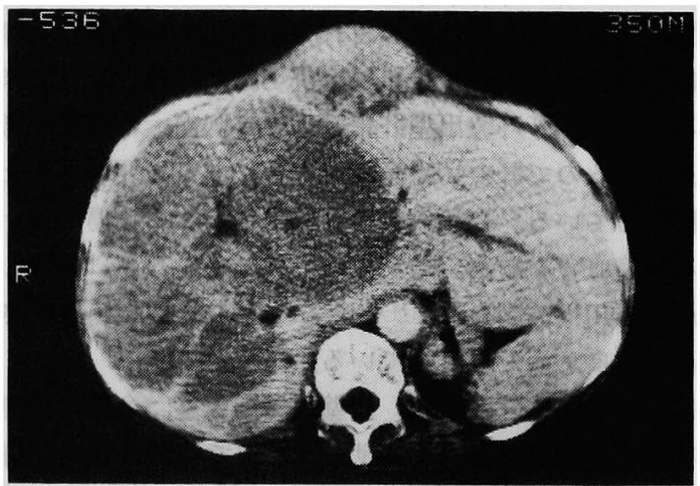

図 5 S62. 11. 6. の CT 像：肝内転移巣は巨大化し 腹壁にも転移が認められる。 
月14日，第 8 回昭和63年 5 月20日〜 6 月11日。この期 間はシスプラチン $25 \mathrm{mg} \times 7$ (iv) を投与するむ肝内転 移，腹腔内転移巣は更に増大し別に上腹部腹壁内にも 転移栄が出現し全身衰弱す進行し腸通過障害す増し全 経過 4 年で死亡した（図 5 ）。なお，死亡時にはGOT 221IU, GPT 469IU, LDH 500WU, ALP 281IU と肝 機能障害は認めたものの T-Bi $0.7 \mathrm{mg} / \mathrm{dl}$ ，黄疸なく肝 不全状態は認められなかった。 また, AFP 23ng/ml, CEA 2.2ng/ml, CA19-9 56.5U と隀晹マーカーは陰性 であった。

\section{考 案}

自験例の肝細胞澏は 3 つの特徵を有していた。第 1 に右肝動脈前下区域枝により栄養された肝外発育型の 旰細胞癌で肝組織より直接進展していること，第 2 に 肝内，腹壁筋層内，腹腔内に多数の大きな転移を認め ながらる肝不全に陥ることなく 4 年生存し得たこと, 第 3 に EdII-III の索状型, 充実型, 偽腺管型, 硬化型, また，著しく血管に富む部分等多彩な組織像を呈した ことである。

肝外発育型肝癌は遠近 告され男43例，女17例（不明 2) で男性に多く発生部 位は右葉32例，左葉23例とやや右葉原発が優位である とい5。市川市は肝外発育型肝細胞癌 6 例を経験しそ の分析からこれを $\mathrm{A}$ ：肝との連続性の無い異所性発 育型肝細胞癌 B：肝之連続性を有する肝外発育型肝細 胞癌に分類し更に $\mathrm{B}$ を $\mathrm{a}$ ：有茥型と $\mathrm{b}$ ：肝外突出型に 分類した。本症例は拡張した右前下区域枝より直接栄 養され肝とは肝内で薄い被膜で境界されているのみで 結合織による茥を認めなかったので市川の分類 ${ }^{2} に よ$ れば肝外発育型のうち肝外突出型肝細胞癌の範罟に入 る. 河野3らも自験例に類似した症例を報告している が同様の発生母地が考兄られる。市川党は有茎型肝細 胞癌は肝と結合織で境界されているために肝臓の切除 は少なくてすむが他䑏器の合併切除が必要になって来 るのに反し旰外突出型肝細胞癌では肝内への進展も考 えられるので肝の切除範囲を大きく取る必要があると 指摘している，自験例では肝被膜に沿って腫㻛にはい る栄着血管を順次，結禁切断して腫湯を容易に摘除し たが市川2の指摘どらりであるなら右葉切除が選択さ れても良かったと考えている。

自験例では肝内転移，腹壁筋層内転移，多数の腹腔 内転移が認められたが遠近”の報告では肝外発育型肝 細胞癌62例中肝内転移は22例(35.4\%), 遠隔転移は14 例 $(22.5 \%$ ）飞認められたという。一般に原発性肝細
胞癌の剖験例では全ての癌の終末像と同様に多くの灆 器に転移が認められている(4)-6). 特に, 肝細胞癌では肺 転移が多く日本肝癌研究会7の報告では剖験例951例 中444例 (46.7\%) に肺転移が認められている。また， 腹腔内転移 $17.6 \%$, 皮府転移 $1.6 \%$ と報告されているが 自験例の上5に腹壁筋㬝内転移については報告例を見 ずまれなるのと考克られる，自験例では肝内転移が発 見されてから 3 年間, また，腹腔内転移が発見されて から 2 年間生存し得たがこの間, 肝臓機能には大きな 障害を認めず，患者の入退院を綝り返した理由の中心 は腹腔内転移巣による腸の通過障害, また，栄養障害 に上る全身衰弱であった。初回手術後 2 回転移巣を摘 除しているがいずれあ原発巣と類似の組織像を認め た.この間，転移巣は全身状態の推移にともない軽度 腫大したり縮小したりする傾向が認められたがこれは 血管腫なみに増生した腫煬内血管内の血液の眝留状態 を反映していたすのと考えられた。

自験例の組織像は図に示したように EdII〜III を示 し，また，索状型，充実型，偽腺管型，硬化型と多彩 な組織像を呈していた。遠位 ${ }^{1}$ の報告に依れば EdI〜II

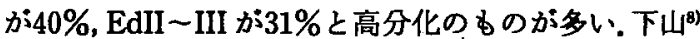
む 4 例の肝外発育型の肝細胞癌を報告しているがいすす れも異形性は多彩で EdI III の肝細胞癌が混在して いたとい5.

自験例は全経過 4 年で死亡したが肝外発育型肝細胞 癌は巨大な進行癌で発見される場合が多く予後は余り 良くない，遠位”によれば 3 年以上生存した症例は 1 例のみであま, 調査時点で 3 年以上生存していた症例 は 1 例のみであった。 また，下山放によれば 3 年以上の 生存例は 2 例のみで多くは 1 年 1 カ月以内に死亡して いる. 自験例は多数の転移を有しながらす術後早期に は抗癌剂の経口投与，その後の静那投与，2回の肝動 脈注と全身管理により 4 年間生存しえた。本邦報告例 では 4 年を越えて生存した症例はなく生存期間から いっても稀な症例と言える。

\section{文献}

1）迋近裕宣，木田晴海，中山博司他：有形性肝細胞癌 の 1 手術例と本邦報告 62 例の検討, 日臨外医会誌 $50: 148-155,1989$

2）市川 長, 今岡真羲, 佐々木洋他：肝外発育型肝細 胞癌 6 例の検討一肝外発育型肝細胞癌の分類之外 科治療，肝䠞 $25: 806-812,1984$

3）河野仁志，古賀俊六，谷浦博之他：術前に診断され た有形性肝細胞癌の 1 切除例，日消外会誌 20 
98-101, 1987

4) Edmondson HA, Steiner PE: Primary carcinoma of the liver. A study of 100 cases among 48,900 necropsies. Cancer $7: 462-503,1954$

5) MacDonald RA: Primary carcinoma of the liver-A clinicopathological study of one hundred eight cases. AMA Arch Intern Med 99 : 266 $-279,1957$
6）荒木嘉隆，宮崎達男：原発性肝癌一日本人訮癌の 臨床統計的研究一，日臨 $32: 2231-1162,1974$

7）日本肝癌研究会編：第 8 回全国原発性肝癌追跡調 查報告 (1984-1985). 日本肝癌研究会事務局，京 都, 1988, p99

8）下山孝俊, 福田 豊, 川口昭男他：有形性肝細胞癌 の踟床一自験 4 例と本邦例の病理形態学的検討 一, 肝荿 $27: 227-233,1986$

\title{
A 4-YEAR SURVIVAL CASE OF PROTRUSIVE TYPE OF HEPATOCELLULAR CARCINOMA WITH METASTASES OF THE LIVER, ABDOMINAL CAVITY AND ABDOMINAL WALL
}

\author{
Kimitaka KOGURE, Masatoshi ISHIZAKI, Masaaki NEMOTO, Mitsuo NAKAYA, \\ Tetsu ANDO, Tooru KURIBARA and Kiyoshi SASAMOTO* \\ First Department of Surgery, Gumma University, School of Medicine \\ (Prof. Yukio NAGAMACHI) \\ *Saiseikai Maebashi Hospital
}

A 58-year-old woman who copmplained of a weight loss and change in the sence of taste was admitted due to a large abdominal mass on the right upper quadrant. Echography, computed tomography and angiography revealed the large hepatic tumor which was fed by the right anterior inferior branch of hepatic artery. After a ligation of the right hepatic artery the tumor was extirpated by the dissection of the feeding vessels. It showed a variety of histological features such as funicular, solid, pseudoductal, and indurated ones. After 15 months the metastases were noticed in the abdominal wall and liver, however, one of the lesions only in the abdomial wall could be extirpated. After 19 months the intrahepatic metastases became bigger and now metastasis was observed in the peritoneal cavity. After 30 months the metastses of the jejunal mesenterium was extirpated to prevent the intestinal obstruction. After $\mathbf{4 8}$ months she died of cahexia due to the enlarged metastatic tumors and the disturbance of the intestinal passing. This case can be classified into the protrusive type among the extrahepatic growing type of hepatocellular carcinomas according to the classification by Ichikawa. It can be said rare in the survival period for as long as 4 years that is the longest one among 62 cases of this classification reported in Japan. 